\title{
Acclimation of seagrass Zostera noltii to co-occurring hydrodynamic and light stresses
}

\author{
Carmen B. de los Santos ${ }^{1, *}$, Fernando G. Brun ${ }^{1,2}$, Tjeerd J. Bouma ${ }^{2}$, Juan J. Vergara ${ }^{1}$, \\ J. Lucas Pérez-Lloréns ${ }^{1}$ \\ ${ }^{1}$ Department of Biology, University of Cádiz, PO Box 40, 11510 Puerto Real (Cádiz), Spain \\ ${ }^{2}$ Netherlands Institute of Ecology (NIOO-KNAW), Centre for Estuarine and Marine Ecology, PO Box 140, 4400 AC Yerseke, \\ The Netherlands
}

\begin{abstract}
Seagrasses may frequently experience a combination of velocity and light stresses, as elevated hydrodynamics often enhances turbidity and the subsequent light reduction. The objective of this study was to investigate the effects that these stressors induce on morphometric and dynamic seagrass features depending on the initial biomass partitioning. For this purpose, a factorial mesocosm experiment was conducted on plants of Zostera noltii subjected to combinations of 2 contrast-

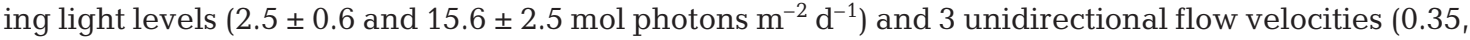
0.10 and $0.01 \mathrm{~m} \mathrm{~s}^{-1}$ ). No interactive effects between the 2 variables were recorded, except on plant survival and leaf length, and generally, light effects prevailed over hydrodynamic ones. Plants responded to light reduction regardless of the flow velocity treatments, showing low survival rates (which improved at high velocity), high aboveground/belowground biomass ratios (AG/BG) and a poorly developed root-rhizome system compared to plants under saturating light conditions. Plant morphometry only responded to hydrodynamic stress under saturating light: at high current velocity, plants preferentially allocated biomass into BG structures, bearing short leaves and displaying high internode and root appearance rates. Overall, light reduction promoted similar responses in plants with different AG/BG biomass ratios, but dissimilarities were recorded for current velocity. Thus, it can be concluded that, under simultaneous light and hydrodynamic stresses, light effects prevailed over hydrodynamic ones in $Z$. noltii, while acclimation to hydrodynamics only occurred under saturating light.
\end{abstract}

KEY WORDS: Aboveground/belowground biomass ratio · Acclimation $\cdot$ Hydrodynamics $\cdot$ Light reduction · Flume tank · Multiple stressors $\cdot$ Phenotypic plasticity $\cdot$ Zostera noltii

\section{INTRODUCTION}

Shallow marine habitats, and especially intertidal zones, are characterised by large variability in physico-chemical conditions, which are often influenced by anthropogenic activities (Mann 2000). This environmental variability imposes a strong effect on the surrounding biota, usually being considered as stress when it results in reduced organism growth and/or survival. Zostera noltii Horneman is a temperate seagrass that often inhabits intertidal zones. Being rooted organisms, they cannot avoid the occurrence of abiotic stresses, which must be partly overcome through phenotypic plasticity, i.e. through adjustments in metabolic, physiological and morphological traits (Sultan 1987, Pigliucci 2001). Morphological plasticity in clonal plants has been interpreted as an acclimation mechanism (also called acclimatization) (Sultan 2000, Peralta et al. 2005, Brun et al. 2006b), improving ecological breadth and fitness and, thus, survival and colonization success of the species (Bazzaz 1996, DeWitt et al. 1998, Sultan et al. 1998).

Since different abiotic stresses may drive opposite or diverse phenotypic responses, it is difficult to predict 
how organisms will respond to interactive stresses. This is the case of seagrass response to 2 commonly cooccurring stresses: high hydrodynamic forces and low light availability. Both conditions often co-occur since a high hydrodynamic energy may promote sediment resuspension, and thus a reduction of the light availability.

Plant adjustments to water velocity involving changes in morphometry, architecture and dynamic traits have been demonstrated in seagrasses (Peralta et al. 2006; reviewed in Koch et al. 2006). In high hydrodynamic energy environments, the most common plant response is a preferential biomass allocation into belowground (BG) tissues (Schanz \& Asmus 2003, Peralta et al. 2005, 2006). Accordingly, the ratio between carbon-source tissues (aboveground, AG) and carbonsink tissues (BG) is altered, as well as the overall growth efficiency. Additionally, increased BG biomass becomes a disadvantage under limiting light conditions, since the root-rhizome system relies on the basipetal translocation of carbon and oxygen produced in the AG structures during photosynthesis (Hemminga 1998). Thus, such acclimation responses to enhanced current velocity might reduce the plant fitness and make seagrasses more vulnerable to other environmental stressors such as light deprivation.

On the other hand, acclimation to light reduction also involves direct effects on biomass allocation, physiology and morphometry (Peralta et al. 2002, reviewed in Lee et al. 2007). Light is the single most important driver for photosynthesis, providing energy for carbon fixation. Therefore, under low light availability, plants will invest a higher proportion of energy in the formation of leaves, while the development of the BG network will be restricted, reducing the maintenance costs of the non-photosynthetic tissues (Hemminga \& Duarte, 2000). Additionally, a compensatory morphological response has been reported in experimentally manipulated Zostera noltii plants depending on their AG/BG biomass ratio (Olivé et al. 2007), i.e. shoot production was stimulated by a low AG/BG biomass ratio, whereas rhizome and root production occurred in plants with a large AG/BG biomass ratio. This compensatory response was more noticeable in plants grown under limiting light, indicating the important role of biomass partitioning in coping with adverse or stressful environmental conditions (Hemminga 1998, Olivé et al. 2007).

Consequently, available literature on hydrodynamic and light stresses indicates that Zostera noltii acclimation to these stressors requires opposing growth responses. Particularly, biomass allocation into AG structures is favoured by light reduction whereas increased BG network is found under high hydrodynamic forces. In this study, the responses of $Z$. noltii plants with low and high AG/BG biomass ratios to different light and hydrodynamic levels were tested using a factorial mesocosm experiment. Specifically, the following questions are addressed in the present work: (1) Has the combination of hydrodynamic stress and light reduction any interactive effect on morphometric and dynamic features? (2) What are the principal growth responses when both stresses co-occur? (3) Does the initial biomass partitioning (AG/BG biomass ratio) determine the responses to this combination of environmental stressors?

\section{MATERIALS AND METHODS}

Biological material. The experiment was conducted on the temperate seagrass Zostera noltii Horneman, characterised by high growth rates and large morphometric plasticity, both of which are affected by light conditions (Brun et al. 2003b, Peralta et al. 2005) and current velocity (Peralta et al. 2006). Zostera noltii is a clonal plant formed by small leaf bundles (i.e. shoots) bearing 2 to 5 narrow leaves attached to a plagiotropic (i.e. horizontal) rhizome. Each rhizome holds many shoots on short branches separated by rhizome segments (internodes), and 1 to 4 thin roots arising from each rhizome node (Brun et al. 2006a). Specimens were haphazardly collected in mid-September from an intertidal bed at Los Toruños salt marsh (Cádiz Bay Natural Park; 36³0' N, 6¹0' W, Cádiz, Southern Spain; mean temperature in September $=23.3^{\circ} \mathrm{C}, \mathrm{S}=$ 34), $10 \mathrm{~d}$ before starting the experiments. For testing the effect of the initial biomass partitioning on $Z$. noltii response, single and apical experimental plant units (EPUs), with high and low AG/BG biomass ratios, respectively, were selected. Apical EPUs consisted of 2 rhizome internodes with 1 apical shoot and 1 lateral shoot, and the associated roots, whereas single EPUs consisted of a single small shoot, with a leaf bundle, a small proportion of rhizome and the associated roots. Plants were cleaned, wrapped in moist tissue paper and sent to the NIOO-CEME laboratory (The Netherlands). Upon arrival, plants were kept in a filtered natural seawater tank with aeration and saturating light until they were planted for the experiment.

Experimental set-up. The mesocosm experiment, conducted at the NIOO-CEME laboratory, lasted $46 \mathrm{~d}$ (from 27 September to 12 November). The experimental design consisted of 12 small flume tanks provided with independent pumping systems (Fig. 1). The flume tanks were grouped in 3 unidirectional current velocity regimes. That is, 4 independent small flume tanks (replicates) for each velocity treatment: low (LV), medium (MV), and high velocities (HV), corresponding approximately to $0.01,0.10$ and $0.35 \mathrm{~m} \mathrm{~s}^{-1}$ (veloci- 


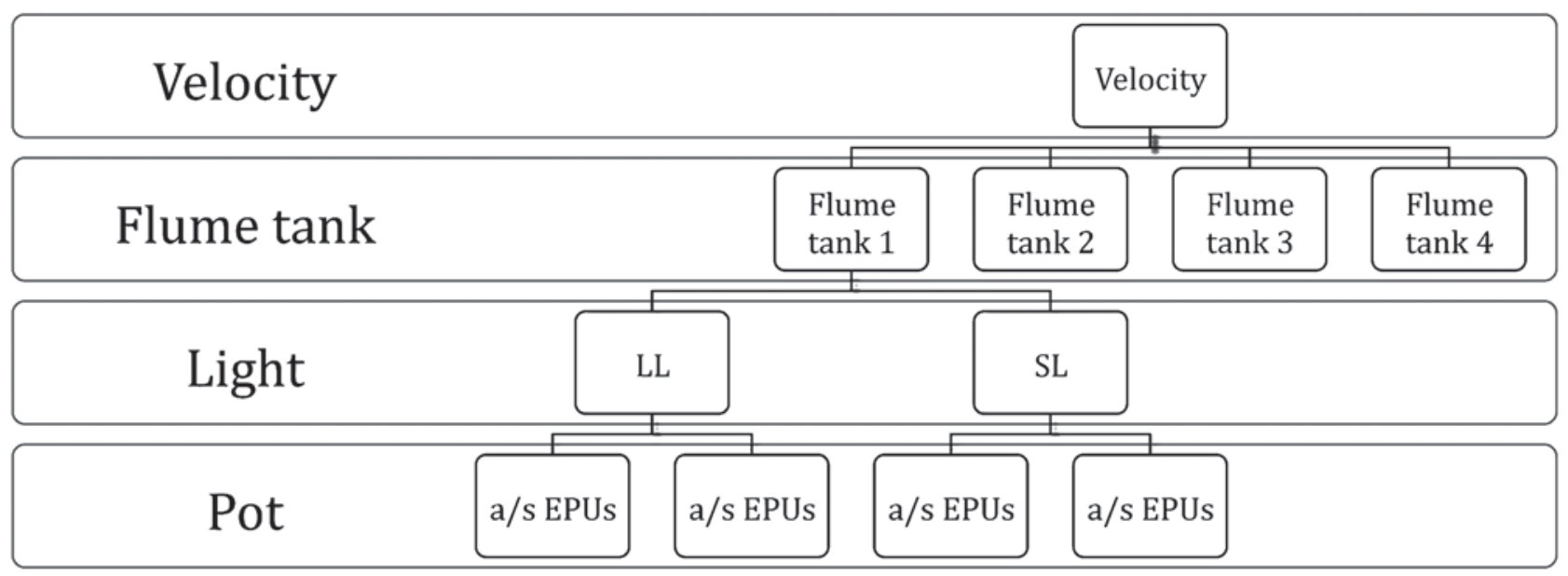

Fig. 1. Experimental design, consisting of 3 velocity treatments (high, medium and low velocity), each one with 4 independent replicates (flume tanks). Two pots within each tank were exposed to limiting light (LL) and the other 2 to saturating light (SL). In each pot, 3 single (s) experimental plant units (EPUs) and 3 apical (a) EPUs were transplanted (sub-replicates). See 'Materials and methods' for more details

ties measured with a ADV Doppler Nortek at $25 \mathrm{~Hz}$; see Peralta et al. 2006 for further technical information). These velocity treatments were selected according to the range observed on tidal flats bordering intertidal vegetations (Bouma et al. 2005b) and the velocity range registered in the Zostera noltii beds in Cádiz Bay: from $0.02 \mathrm{~m} \mathrm{~s}^{-1}$ to exceptionally $0.25 \mathrm{~m} \mathrm{~s}^{-1}$ (M. Lara pers. comm.). As there are studies reporting a decrease in growth of Zostera spp. at high velocities (0.25 to $0.37 \mathrm{~m} \mathrm{~s}^{-1}$ in Fonseca \& Bell 1998; $0.26 \mathrm{~m} \mathrm{~s}^{-1}$ in Schanz \& Asmus 2003) and the HV treatment exceeds these field measurements, this treatment was considered as stressful for the plants.

After being rinsed and carefully cleaned with seawater, 3 apical EPUs and 3 single EPUs (pseudo-replicates) were haphazardly transplanted into a pot $(12 \times$ $12 \times 25 \mathrm{~cm}$ ) with a homogenous mixture of clay, sand and gravel $\left(Q_{50}=407.2 \mu \mathrm{m}\right)$. Apical and single EPUs were planted with enough separation between them to avoid direct contact or interaction. Subsequently, 4 pots were randomly positioned within each flume tank (i.e. a total of 12 EPUs of each kind per flume tank) and kept for a $1 \mathrm{wk}$ pre-acclimation period under saturating light and at the same temperature and seawater conditions as those used for the subsequent experimental set-up. After pre-acclimation, the experiment started when 2 of the 4 pots per flume tank were shaded with a neutral light-quality screen and the current velocity was applied in each flume tank (Fig. 1). Two contrasting daily-integrated photon irradiances, $2.5 \pm 0.6$ and $15.6 \pm 2.5$ mol photons $\mathrm{m}^{-2} \mathrm{~d}^{-1}$ (mean \pm standard deviation; $\mathrm{n}=12$ ), corresponding to limiting light (LL) and saturating light (SL) levels for Zostera noltii, respectively (Peralta et al. 2002), were set up with an 18 h light:6h dark cycle. Temperature was controlled using independent cooling units for each flume tank and set at $19.5^{\circ} \mathrm{C}$, a value within the optimal temperature range for $Z$. noltii (Peralta et al. 2002). Flume tanks were filled with $2 \mu \mathrm{m}$ filtered Oosterschelde water (south-west Netherlands, salinity $=30$ ) and renewed every $3 \mathrm{~d}$ to avoid nutrient depletion and changes in nutrient availability. Seawater samples were analysed for nutrient content using a San Plus segmented flow Skalar Autoanalyser® (model 8805; analytical limit of detection was $100 \mathrm{ppb}$ ). Nutrient concentrations did not show significant fluctuations during the experiment ( $t$-test on measurements before and after water renewal in each flume tank, $\mathrm{df}=11, \mathrm{p}>$ 0.05 for all nutrients). The mean concentrations throughout the experiment were $0.27 \pm 0.48 \mathrm{\mu M} \mathrm{NH}_{4}{ }^{+}$, $0.17 \pm 0.10 \mu \mathrm{M} \mathrm{NO}_{2}{ }^{-}, 1.59 \pm 1.48 \mu \mathrm{M} \mathrm{NO}_{3}{ }^{-}$and $0.22 \pm$ $0.15 \mu \mathrm{M} \mathrm{PO}_{4}{ }^{3-}$ (mean \pm standard deviation; $\mathrm{n}=12$ ).

Biological measurements. Initial morphometric measurements were conducted separately on a pool of 15 apical and single EPUs at the onset of the experiment, before the pre-acclimation period (Tables 1 \& 2). Additionally, prior to being transplanted, each EPU was weighed (fresh weight, FW) and each rhizome individually tagged. At the end of the experiment, all plant material was carefully harvested to keep rhizomes and roots intact. Then, each EPU was individually weighed (FW) and morphometric measurements were carried out on all of them. Furthermore, each harvested EPU was divided into modules (leaves, rhizome and roots), dried $\left(60^{\circ} \mathrm{C}\right.$, until constant weight, DW) and weighed to calculate the AG/BG ratio. Morphometric information was used to estimate plant dynamic properties, according to Peralta et al. (2000) (Table 1). 
Table 1. Zostera noltii. Morphometric and dynamic features of initial and harvested experimental plant units (EPUs see 'Materials and methods', 'Biological material' for description) measured or calculated in this study. $D_{1}$ and $D_{2}$ : main rhizome diameters. Subscript $i=1,2,3 \ldots n$ : each root, leaf or internode in an EPU. Subscripts $\mathrm{f}$ and 0: final and initial conditions, respectively. $M_{0}$ : meristems activated initially. $M_{\mathrm{A}}$ : meristems activated during the experimental period. $t$ : experimental time (d)

\begin{tabular}{|c|c|c|}
\hline Traits & Units & Description \\
\hline Aboveground biomass (AG) & g DW plant ${ }^{-1}$ & Leaf dried biomass \\
\hline Belowground biomass (BG) & g DW plant ${ }^{-1}$ & Rhizome and root dried biomass \\
\hline Aboveground/belowground biomass (AG/BG) & dimensionless & $\mathrm{AG} / \mathrm{BG}=\frac{\mathrm{AG}}{\mathrm{BG}}$ \\
\hline Leaf abundance (LA) & no. shoot $^{-1}$ & Mean value for all the shoots in an EPU \\
\hline Leaf length (LL) & $\mathrm{cm}$ & Mean value for all the shoots in an EPU \\
\hline Leaf width (LW) & $\mathrm{mm}$ & Mean value for all the shoots in an EPU \\
\hline Leaf thickness (LT) & $\mathrm{mm}$ & Mean value for all the shoots in an EPU \\
\hline Leaf cross-section $\left(L_{\mathrm{sec}}\right)$ & $\mathrm{mm}^{2}$ & $L_{\mathrm{sec}}=\frac{\mathrm{LT}}{\mathrm{Q}} \cdot \frac{\mathrm{LW}}{2 \pi}$ \\
\hline Internode abundance (IA) & no. EPU ${ }^{-1}$ & $L_{\mathrm{sec}}-\frac{2}{2} \quad 2$ \\
\hline Internode length (IL) & $\mathrm{cm}$ & Mean value for all the shoots in an EPU \\
\hline Internode cross-section $\left(I_{\mathrm{sec}}\right)$ & $\mathrm{mm}^{2}$ & $I_{\mathrm{sec}}=\frac{D_{1}}{2} \cdot \frac{D_{2}}{2} \cdot \pi$ \\
\hline Root abundance (RA) & no. $\mathrm{EPU}^{-1}$ & \\
\hline Root length (RL) & $\mathrm{cm}$ & Mean value for all the shoots in an EPU \\
\hline Survival rate (SR) & dimensionless (\%) & $\mathrm{SR}=\frac{\text { LiveEPUs }}{\text { InitialEPUs }} 100$ \\
\hline Growth rate $(\mathrm{GR})$ & $g \mathrm{FW} \mathrm{d}^{-1} \mathrm{EPU}^{-1}$ & $\mathrm{GR}=\frac{\text { Biomass }_{\mathrm{f}}-\text { Biomass }_{0}}{t_{\mathrm{f}}-t_{0}}$ \\
\hline Shoot appearance rate (SAR) & no. $d^{-1} E^{-1}$ & $\mathrm{SAR}=\frac{\sum M_{\mathrm{A}}}{\sum M_{0}} \cdot \frac{1}{\left(t_{\mathrm{f}}-t_{0}\right)}$ \\
\hline Internode appearance rate (IAR) & no. $d^{-1} E^{-1}$ & $\mathrm{IAR}=\frac{\mathrm{IA}_{\mathrm{f}}-\mathrm{IA}_{0}}{t_{\mathrm{f}}-t_{0}}$ \\
\hline Internode elongation rate (IER) & $\mathrm{cm} \mathrm{d}^{-1} \mathrm{EPU}^{-1}$ & $\mathrm{IER}=\frac{\sum_{i=1}^{n}\left(\mathrm{IL}_{i, \mathrm{f}}-\mathrm{IL}_{i, 0}\right)}{t_{\mathrm{f}}-t_{0}}$ \\
\hline Root appearance rate (RAR) & no. $\mathrm{d}^{-1}$ plant $^{-1}$ & $\mathrm{RAR}=\frac{\mathrm{RA}_{\mathrm{f}}-\mathrm{RA}_{0}}{t_{\mathrm{f}}-t_{0}}$ \\
\hline Total root length (TRL) & $\mathrm{cm}$ & $\mathrm{TRL}=\sum_{i=1}^{n} \mathrm{RL}_{i}$ \\
\hline
\end{tabular}

Statistical analysis. Differences in initial features between apical and single EPUs and also between nutrient concentration before and after water renewal were tested by a 2-sample Student's $t$-test for independent samples. In the factorial design, the experimental plots (independent tanks) were replicated (4) and nested in each Light $\times$ Velocity level, to allow an estimate of the intrinsic variability among tanks (Underwood 1997). Additionally, within each tank and under each Light $\times$ Velocity level, 12 plants (6 apical and 6 single EPUs) were transplanted into pots and considered as pseudo-replicates (Fig.1). The effect of each factor and the interaction Light $\times$ Velocity was tested independently for apical and single EPUs using a 3-way nested ANOVA, followed by Tukey's post hoc test, or Tukey's unequal $\mathrm{N}$ honestly significant difference (HSD) test for multiple comparisons when necessary (Sokal \& Rohlf 1995). In the 3-way nested ANOVA the sources of variation were (1) velocity treatment, (2) light treatment, and (3) flume tank nested to velocity. Heteroscedasticity and normality of the data were tested and transformations were carried out when necessary. In all cases, the level of significance was set at $5 \%$.

\section{RESULTS}

The interactive effects of light and velocity were assessed by a 3-way ANOVA, and no significant effect 
Table 2. Zostera noltii. Initial morphometric features of a pool of experimental plant units (EPUs) collected separately at the onset of the experiments (mean $\pm S E ; n=15$ ). $t$ : 2-sample Student's $t$-value, for comparing initial features between apical and single EPUs; df: degree of freedom; p: significance: ${ }^{* * *} \mathrm{p}<0.001{ }^{* *} \mathrm{p}<0.01{ }^{*}{ }^{*} \mathrm{p}<$ 0.05). See Table 1 for variable descriptions

\begin{tabular}{|lccc|}
\hline Feature (units) & Apical EPUs & Single EPUs & $t(\mathrm{df}=28)$ \\
\hline Aboveground (AG) biomass (g DW) & $0.022 \pm 0.011$ & $0.019 \pm 0.011$ & 0.56 \\
Belowground (BG) biomass (g DW) & $0.012 \pm 0.003$ & $0.005 \pm 0.002$ & $6.69^{* * *}$ \\
AG/BG biomass ratio & $2.13 \pm 1.35$ & $3.94 \pm 1.64$ & $-3.31^{* *}$ \\
Leaf abundance (no. shoot ${ }^{-1}$ ) & $2.6 \pm 0.5$ & $3.1 \pm 0.6$ & $-2.62^{* *}$ \\
Leaf length (cm) & $9.5 \pm 2.9$ & $13.0 \pm 5.2$ & $-2.34^{*}$ \\
Leaf width (mm) & $1.13 \pm 0.13$ & $1.28 \pm 0.17$ & $-2.69^{*}$ \\
Leaf thickness (mm) & $0.14 \pm 0.14$ & $0.15 \pm 0.04$ & -0.39 \\
Leaf cross-section (mm $\left.{ }^{2}\right)$ & $0.13 \pm 0.13$ & $0.16 \pm 0.06$ & -0.89 \\
Internode length (cm) & $1.07 \pm 0.47$ & $0.23 \pm 0.09$ & $6.77^{* * *}$ \\
Internode cross-section $\left(\mathrm{mm}^{2}\right)$ & $1.63 \pm 0.39$ & $1.55 \pm 0.33$ & 0.61 \\
Root abundance $\left(\mathrm{no} . \mathrm{shoot}^{-1}\right)$ & $3.1 \pm 1.8$ & $4.2 \pm 2.2$ & -1.48 \\
Root length (cm) & $3.16 \pm 1.26$ & $4.55 \pm 1.38$ & $-2.81^{* *}$ \\
\hline
\end{tabular}

under MV and LL the AG biomass exceeded the BG biomass (AG/BG > $1)$. The net growth rate of plants under LL was only positive at $\mathrm{HV}$, whereas negative values were recorded in EPUs at LV and MV (apical EPUs; Fig. 2). In the case of single EPUs, survival rate under saturating light was higher at LV than at MV or HV, and internode appearance rate was higher at MV (Fig. 2).

At the onset of the experiment, apical and single EPUs had contrasting AG/BG biomass ratios $(2.1 \pm 1.4$ and $3.9 \pm 1.6$, respectively; Table 2). At the end of the experiment, morphometric and dynamic properties of both types of EPUs were affected similarly by light but

of tank was detected (Table 3). Interactions were only detected for survival rate of single EPUs and leaf length of apical EPUs. Survival rate for single EPUs was significantly lower in both MV and HV treatments compared to LV under saturating light levels (Fig. 2). Apical EPUs bore shorter leaves under SL except when growing at LV, where no difference was found between light treatments (Fig. 3).

Overall, dynamic features of both types of EPUs were significantly affected by light regardless of the velocity treatment, with higher survival and growth rates, and higher appearance rates for shoots (only for apical EPUs), internodes and roots under SL conditions (Table 3, Fig. 2). Generally, light affected the morphometry of apical and single EPUs in a similar way: plants under LL had longer leaves, higher AG/BG biomass ratios, lower root abundance and lower shoot abundance than those growing under SL conditions (Fig. 3).

Velocity effects were observed only for a few morphometric features, mostly in apical EPUs (Table 3): leaf length decreased from LV to HV, internodes were longer at $\mathrm{HV}$ than at $\mathrm{MV}$ or $\mathrm{LV}$, and total root length was also affected (Fig. 3). Contrastingly, only single EPUs showed significant differences when testing the effect of velocity on the AG/BG biomass ratio (Table 3, Fig. 3): under $\mathrm{HV}$ and LV conditions, single EPUs preferentially allocated biomass into BG systems $(\mathrm{AG} / \mathrm{BG}<1)$, whereas not by velocity, which mainly affected the morphometry of apical EPUs (Table 3). Shoot appearance rates of apical EPUs were higher under SL whereas no significant effect was recorded for single EPUs (Fig. 2). However, under MV and SL, some specific single EPUs presented high shoot appearance rates similar to those of apical EPUs (Fig. 2).

Table 3. Zostera noltii. Individual and interactive effects of Light, Velocity and Tank on morphometric and dynamic features based on a 3-way nested ANOVA results. Statistical analyses were performed separately for apical (A/a) and single (S/s) experimental plant units (EPUs). Upper-case letters: significant differences among the treatments $\left({ }^{* * *} \mathrm{p}<0.001 ;{ }^{* * *} \mathrm{p}<0.01 ;{ }^{*} \mathrm{p}<0.05\right)$. Lowercase letters: no significant differences. nd: no data available; AG/BG: aboveground/belowground. When needed, transformations performed on data are given in brackets

\begin{tabular}{|lcccc|}
\hline Feature & Light & Velocity & Tank & $\begin{array}{c}\text { Light } \times \\
\text { Velocity }\end{array}$ \\
\hline Morphometric features & & & & \\
AG/BG biomass ratio & $\mathrm{A}^{* *} / \mathrm{S}^{* * *}$ & $\mathrm{a} / \mathrm{S}^{* * *}$ & $\mathrm{a} / \mathrm{s}$ & $\mathrm{a} / \mathrm{s}$ \\
Leaf abundance & $\mathrm{a} / \mathrm{s}$ & $\mathrm{A}^{*} / \mathrm{s}$ & $\mathrm{a} / \mathrm{s}$ & $\mathrm{a} / \mathrm{s}$ \\
Leaf length & $\mathrm{A}^{* *} / \mathrm{S}^{* * *}$ & $\mathrm{~A}^{* *} / \mathrm{s}$ & $\mathrm{a} / \mathrm{s}$ & $\mathrm{A}^{*} / \mathrm{s}$ \\
Leaf width & $\mathrm{a} / \mathrm{s}$ & $\mathrm{A}^{*} / \mathrm{s}$ & $\mathrm{a} / \mathrm{s}$ & $\mathrm{a} / \mathrm{s}$ \\
Leaf thickness & $\mathrm{a} / \mathrm{s}$ & $\mathrm{a} / \mathrm{s}$ & $\mathrm{a} / \mathrm{s}$ & $\mathrm{a} / \mathrm{s}$ \\
Leaf cross-section & $\mathrm{a} / \mathrm{s}$ & $\mathrm{a} / \mathrm{s}$ & $\mathrm{a} / \mathrm{s}$ & $\mathrm{a} / \mathrm{s}$ \\
Shoot abundance & $\mathrm{A}^{*} / \mathrm{s}$ & $\mathrm{a} / \mathrm{s}$ & $\mathrm{a} / \mathrm{s}$ & $\mathrm{a} / \mathrm{s}$ \\
Internode length & $\mathrm{a} / \mathrm{s}$ & $\mathrm{A}^{* *} / \mathrm{s}$ & $\mathrm{a} / \mathrm{s}$ & $\mathrm{a} / \mathrm{s}$ \\
Internode cross-section & $\mathrm{a} / \mathrm{s}$ & $\mathrm{a} / \mathrm{s}$ & $\mathrm{a} / \mathrm{s}$ & $\mathrm{a} / \mathrm{s}$ \\
Root abundance (Ln) & $\mathrm{A}^{* *} / \mathrm{S}^{* *}$ & $\mathrm{a} / \mathrm{s}$ & $\mathrm{a} / \mathrm{s}$ & $\mathrm{a} / \mathrm{s}$ \\
Root length & $\mathrm{a} / \mathrm{s}$ & $\mathrm{a} / \mathrm{s}$ & $\mathrm{a} / \mathrm{s}$ & $\mathrm{a} / \mathrm{s}$ \\
Total root length & $\mathrm{A}^{* *} / \mathrm{S}^{* *}$ & $\mathrm{a} / \mathrm{s}$ & $\mathrm{a} / \mathrm{s}$ & $\mathrm{a} / \mathrm{s}$ \\
Dynamic features & & & & \\
Survival rate & $\mathrm{A}^{* * *} / \mathrm{S}^{* *}$ & $\mathrm{a} / \mathrm{s}$ & $\mathrm{a} / \mathrm{s}$ & $\mathrm{a} / \mathrm{S}$ \\
Growth rate & $\mathrm{A}^{* *} / \mathrm{s}$ & $\mathrm{a} / \mathrm{s}$ & $\mathrm{a} / \mathrm{s}$ & $\mathrm{a} / \mathrm{s}$ \\
Shoot appearance rate & $\mathrm{A}^{*} / \mathrm{s}$ & $\mathrm{a} / \mathrm{s}$ & $\mathrm{a} / \mathrm{s}$ & $\mathrm{a} / \mathrm{s}$ \\
Internode appearance rate & $\mathrm{A}^{* *} / \mathrm{S}^{* *}$ & $\mathrm{a} / \mathrm{s}$ & $\mathrm{a} / \mathrm{s}$ & $\mathrm{a} / \mathrm{s}$ \\
Internode elongation rate & $\mathrm{A}^{* *} / \mathrm{S}^{*}$ & $\mathrm{a} / \mathrm{s}$ & $\mathrm{a} / \mathrm{s}$ & $\mathrm{a} / \mathrm{s}$ \\
Root appearance rate & $\mathrm{A}^{* *} / \mathrm{S}^{*}$ & $\mathrm{a} / \mathrm{s}$ & $\mathrm{a} / \mathrm{s}$ & $\mathrm{a} / \mathrm{s}$ \\
\hline
\end{tabular}



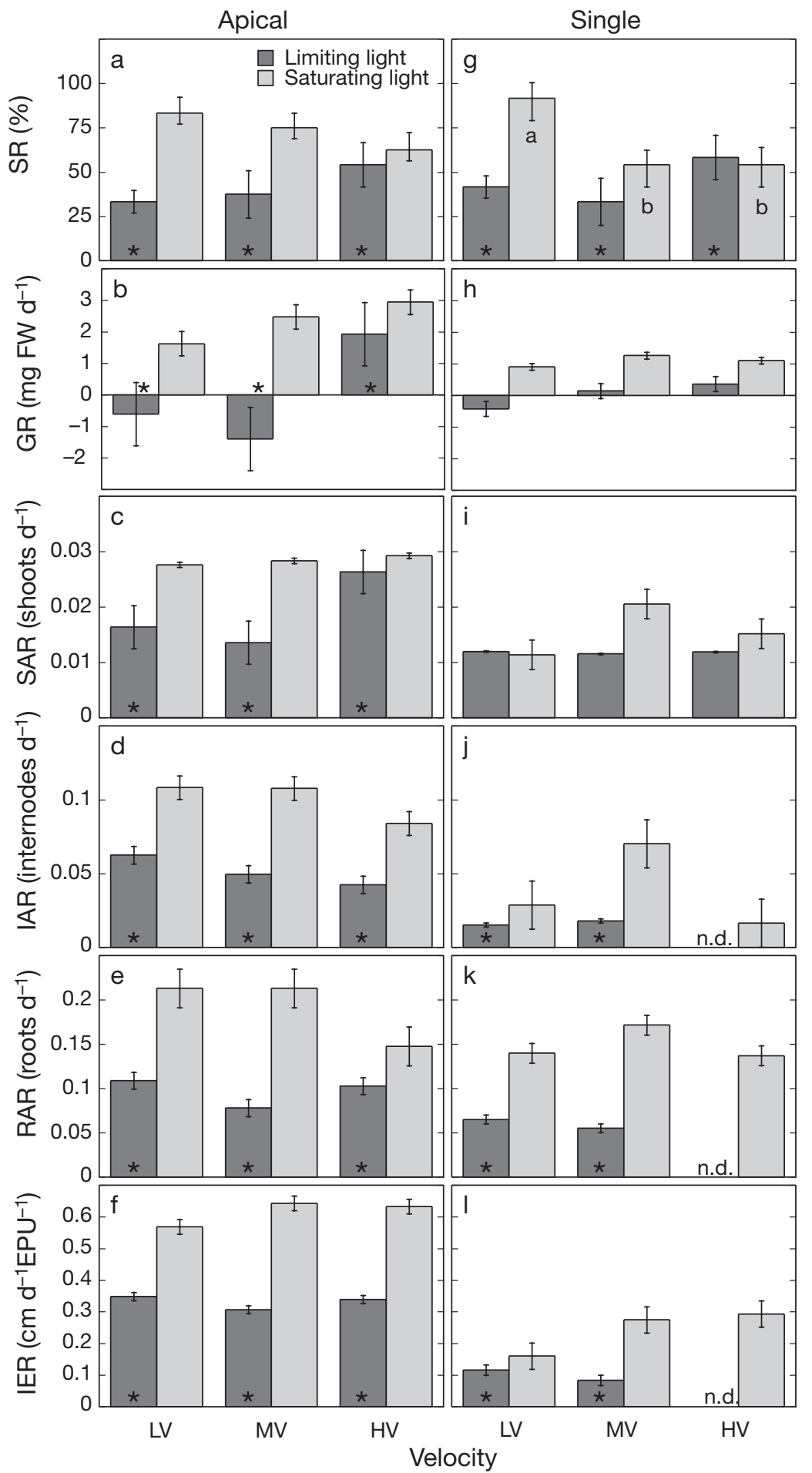

Fig. 2. Zostera noltii. Dynamic features of plants under each Velocity $\times$ Light treatment (mean $\pm \mathrm{SE}):(\mathrm{a}, \mathrm{g})$ survival rate $(\mathrm{SR}),(\mathrm{b}, \mathrm{h})$ growth rate $(\mathrm{GR}),(\mathrm{c}, \mathrm{i})$ shoot appearance rate (SAR), $(\mathrm{d}, \mathrm{j})$ internode appearance rate (IAR), $(\mathrm{e}, \mathrm{k})$ root appearance rate (RAR), and $(f, l)$ internode elongation rate (IER) for $(a-f)$ apical and $(g-l)$ single experimental plant units (EPUs). Asterisks in bars indicate significant differences between light treatments that are independent of the velocity treatment ( 3 -way nested ANOVA). Letters inside bars indicate an interactive effect of light and velocity (3-way nested ANOVA). nd: no data; LV, $\mathrm{MV}, \mathrm{HV}$ : low, medium, high velocity, respectively

\section{DISCUSSION}

According to the present results, it appears that light prevailed as the driving force in acclimation of morphological and dynamic features when both stressors act simultaneously. The strong prevalence of light might be explained by an energy shortage induced by light limitation, constraining the possibilities of the plant to respond to co-occurring stresses.

The observed morphological variations recorded in LL treatments agree with previous findings for the same species (Vermaat \& Verhagen 1996, Hemminga \& Duarte 2000, Peralta et al. 2002, Brun et al. 2003c), showing an increase in leaf length and AG/BG biomass ratio, and reduced appearance and elongation rates of BG modules. Changes in leaf size under reduced light were observed for all velocities, especially at MV and HV. However, light did not affect leaf length of apical EPUs at LV, possibly because of the growth limitation imposed by the low water motion (Ackerman \& Okubo 1993, Koch 1994, Thomas \& Cornelisen 2003). The reduction in leaf length under high current velocity has been widely observed in mesocosm experiments (Peralta et al. 2006), in situ manipulation experiments (Schanz \& Asmus 2003, van Katwijk \& Hermus 2000) and in field observations (Peralta et al. 2005); this size reduction would benefit the plant because it reduces drag forces, thus, minimizing the risks of breakage or uprooting (Bouma et al. 2005a).

The low plant survival and growth rates of BG tissues recorded under LL could be explained by 'cascade effects' and the resulting whole-plant carbon imbalance (Hemminga 1998). Firstly, light reduction triggers this 'cascade effect' which includes (1) an immediate reduction of the basipetal $\mathrm{O}_{2}$ flow from the photosynthetic tissues causing (2) a limited or nil support of the respiration requirements of the root-rhizome system and (3) cessation of the oxygenation of the rhizosphere (Pedersen et al. 1998). Consequently, BG modules may occasionally undergo anaerobic conditions (Smith et al. 1984) and the subsequent 

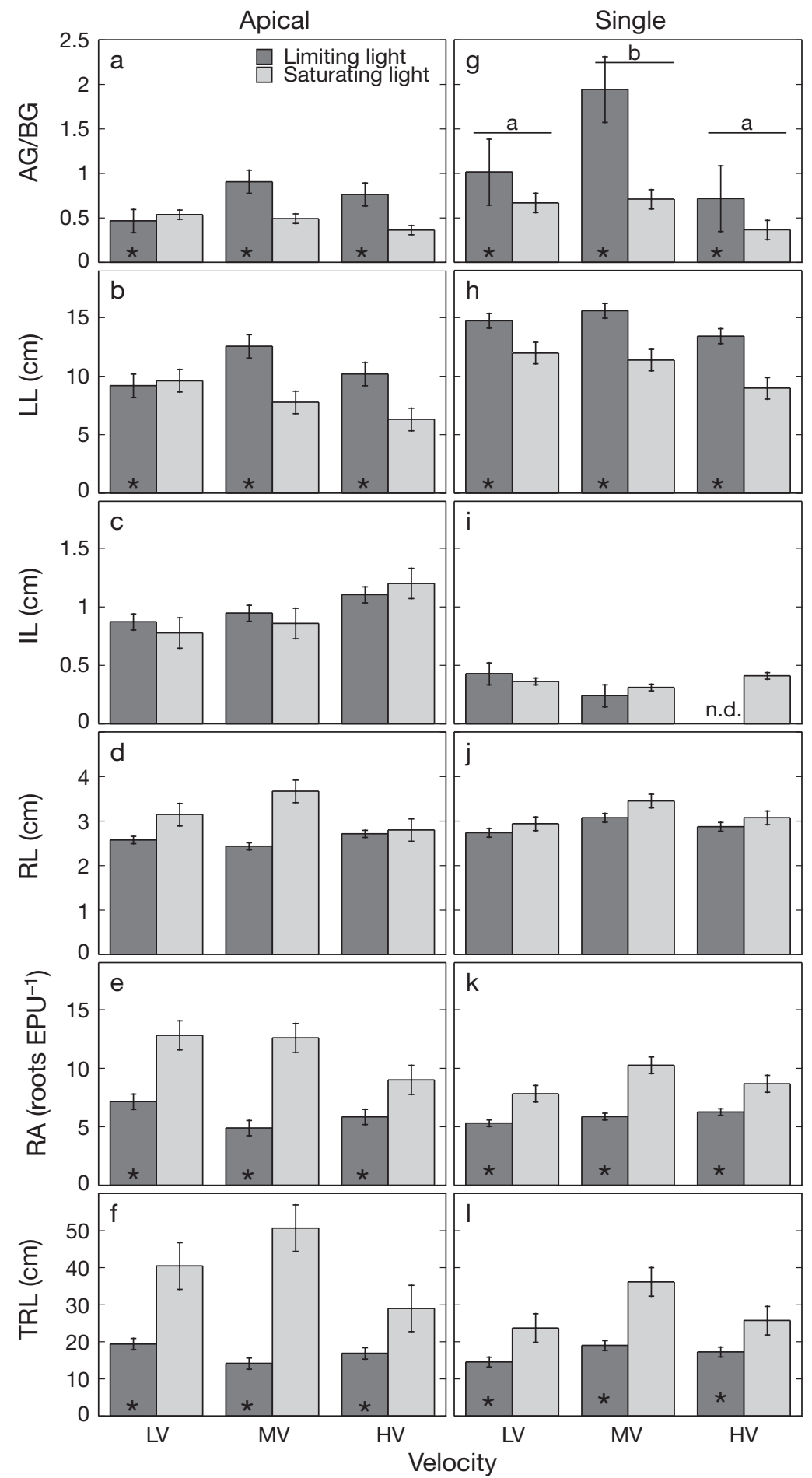

Fig. 3. Zostera noltii. Morphometric properties of plants under each Velocity $\times$ Light treatment (mean $\pm \mathrm{SE}):(\mathrm{a}, \mathrm{g})$ aboveground/belowground biomass partitioning $(A G / B G),(b, h)$ leaf length $(L L),(c, i)$ internode length $(\mathrm{IL}),(d, j)$ root length (RL), (e,k) root abundance (RA), and (f,l) total root length (TRL) for apical $(\mathrm{a}-\mathrm{f})$ and $(\mathrm{g}-\mathrm{l})$ single experimental plant units (EPUs). Lines with letters indicate significant differences between velocity treatments that are independent of light treatment (3-way nested ANOVA) and asterisks in bars show significant differences between light treatments that are independent of velocity treatment (3-way nested ANOVA). nd: no data; LV, MV, HV: low, medium, high velocity, respectively accumulation of phytotoxins derived from the anaerobic metabolism in the sediment cannot be avoided (Hemminga 1998). Secondly, the metabolic adaptation to anoxia (i.e. fermentative sucrose consumption by BG tissues) entails a drain of carbon due to the release of ethanol and other metabolites (Pregnall et al. 1984, Smith et al. 1984), which makes less efficient use of carbon reserves, or even a carbon starvation in the BG tissues if the basipetal translocation of sucrose is blocked during severe anoxia events (Zimmerman et al. 1995, Brun et al. 2003a). Consequently, light deprivation may result in a reduction of the growth and biomass production of BG, an impairment of root-rhizome function and, eventually, in plant death, as recorded in the present study under LL conditions. However, the survival rate of single EPUs was affected by the interaction of light and velocity, reaching higher rates under LL and HV than under LL and MV, or LL and LV (Table 3). This suggests that the above-mentioned negative effects of light reduction on plant survival can be somewhat alleviated by the water motion of the HV treatment. This observation could be explained by the improvement of oxygen diffusion at the sediment-water interface by the high velocity flow (Kemp et al. 1992, Koch et al. 2006), reducing the anoxic or hypoxic conditions in the rootrhizome system, which may cause the low survival rate of the light-limited plants exposed to LV and MV (Greve et al. 2003, Borum et al. 2005). In future studies, it would be interesting to include $\mathrm{O}_{2}$ measurements, both in the water column and for sediment profiles, to asses whether there are velocity effects on the soil redox potential, especially during light deprivation.

This work indicates that light limitation restricts the possibility of acclimation to high velocity and Zostera noltii only acclimates to velocity under saturating light. Also, we found that $\mathrm{HV}$ alleviated the effects of light limitation, increasing the survival rate. In response to HV conditions (at SL), biomass was preferentially allocated into BG parts causing a reduced AG/BG ratio, and some morphometric changes were registered in all the modules (leaves, rhizomes and roots; 
Fig. 2). This response is in agreement with previous studies (Peralta et al. 2005, 2006) and has been interpreted as (1) lessening the uprooting risk, through a stronger anchorage (Peralta et al. 2006), and (2) reducing drag forces caused by flow stress due to smaller shoot size (Puijalon \& Bornette 2004, Peralta et al. 2005, 2006).

Previous studies have demonstrated the interactive effects of hydrodynamic forces and sediment organic matter (Wicks et al. 2009) and light (Fonseca et al. 2007) on the morphology and patch configuration of Zostera marina, respectively. However, the present study is the first to explore the interactive effects of flow and light. Fonseca et al. (2007) hypothesised that water motion may affect light capture due to the flow-driven organisation of the $Z$. marina shoots, increasing the self-shading of the leaves in the meadow. In the present work, Z. noltii leaves were to some extent horizontally positioned in MV and HV treatments due to their high flexibility, whereas they were almost vertical at LV. Nevertheless, the density of the plants in the flume tanks was not high enough to consider the effect of self-shading within a typical canopy. The horizontal position of the leaves at $\mathrm{HV}$ and MV might increase light capture since the projected surface is larger than in the vertical position (LV), thereby benefiting photosynthesis (Zimmerman 2003) and the oxygen basipetal flow to the BG tissues.

As aforementioned, 2 types of Zostera noltii units with contrasting initial AG/BG biomass ratios (i.e. apical and single) were selected to compare their responses to both stressors, light and velocity, and their interaction. Overall, light reduction promoted similar responses in apical and single EPUs, but differences were recorded for current velocity. The lack of response to velocity in single EPUs might be ascribed to the low initial carbon storage in BG biomass, limiting their acclimation response. Thus, single EPUs may take longer to acclimate to new environmental conditions (Brun et al. 2006a,b). Olivé et al. (2007) reported a compensatory mechanism in $Z$. noltii growth depending on the initial AG/BG biomass partitioning. That is, the shoot appearance rate (SAR) was stimulated in plants with low AG/BG biomass ratios, whereas in those with high initial AG/BG biomass ratios, the newly produced biomass was preferentially allocated into BG structures. In the present study, only single EPUs grown under SL and MV presented a higher SAR than the apical EPUs in the same treatment, agreeing with Olivé et al. (2007). However, this pattern was not detected in the other velocity treatments, indicating that MV may be the most favourable velocity condition for the stimulation of the SAR when the initial AG/BG biomass ratio is high.

\section{CONCLUSIONS}

This study shows that, under simultaneous light and hydrodynamic stresses, light is the main driving force in the morphological and growth response of Zostera noltii, while acclimation to hydrodynamic stress only occurs under saturating light. It can be hypothesised that the costs of light limitation will reduce the plant's capacity to cope with hydrodynamic stress but, at the same, the high velocity tested in the present work seems to ameliorate the negative effects of light limitation, increasing survival. This outcome brings further insights into plant acclimation to stressful environments and the consequences for seagrass functioning, distribution and survival.

Acknowledgements. This study was supported by the project CTM2008-00012/MAR (Ministerio de Ciencia e Innovación), by the Junta de Andalucía Excellence Project P08-RNM03783 and by the European contract MEIF-CT-2005-515071. C.B.S. holds a FPU grant from the same Ministry. F.G.B holds a European Reintegration Grant (EU contract MERG-CT2007-205675). We thank G. Peralta for critical comments on the early manuscript, M. Lara for helping with hydrodynamic information, B. Sinke and J. van Soelen for their technical assistance, and 4 anonymous reviewers for their valuable comments. This is NIOO-KNAW publication number 4653.

\section{LITERATURE CITED}

Ackerman JD, Okubo A (1993) Reduced mixing in a marine macrophyte canopy. Funct Ecol 7:305-309

Bazzaz FA (1996) Plants in changing environments: linking physiological, population, and community ecology. Cambridge University Press, Cambridge

Borum J, Pedersen O, Greve TM, Frankovich TA, Zieman JC, Fourqurean JW, Madden CJ (2005) The potential role of plant oxygen and sulphide dynamics in die-off events of the tropical seagrass, Thalassia testudinum. J Ecol 93: 148-158

Bouma TJ, De Vries MB, Low E, Peralta G, Tanczos C, van de Koppel J, Herman PMJ (2005a) Trade-offs related to ecosystem engineering: a case study on stiffness of emerging macrophytes. Ecology 86:2187-2199

Bouma TJ, De Vries MB, Low E, Kusters L, and others (2005b) Flow hydrodynamics on a mudflat and in salt marsh vegetation: identifying general relationships for habitat characterisation. Hydrobiologia 540:259-274

> Brun FG, Hernández I, Vergara JJ, Pérez-Lloréns JL (2003a) Growth, carbon allocation and proteolytic activity in the seagrass Zostera noltii shaded by Ulva canopies. Funct Plant Biol 30:551-560

Brun FG, Pérez-Lloréns JL, Hernández I, Vergara JJ (2003b) Patch distribution and within-patch dynamics of the seagrass Zostera noltii Hornem. in Los Toruños salt-marsh, Cadiz bay, natural park, Spain. Bot Mar 46:513-524

- Brun FG, Vergara JJ, Navarro G, Hernández I, Pérez-Lloréns JL (2003c) Effect of shading by Ulva rigida canopies on growth and carbon balance of the seagrass Zostera noltii. Mar Ecol Prog Ser 265:85-96

> Brun FG, Pérez-Pastor A, Hernández I, Vergara JJ, PérezLloréns JL (2006a) Shoot organization in the seagrass Zostera noltii: implications for space occupation and plant architecture. Helgol Mar Res 60:59-69 
Brun FG, Vergara JJ, Peralta G, García-Sanchez MP, Hernández I, Pérez-Lloréns JL (2006b) Clonal building, simple growth rules and phylloclimate as key steps to develop functional-structural seagrass models. Mar Ecol Prog Ser 323:133-148

DeWitt TJ, Sih A, Wilson DS (1998) Costs and limits of phenotypic plasticity. Trends Ecol Evol 13:77-81

Fonseca MS, Bell SS (1998) Influence of physical setting on seagrass landscapes near Beaufort, North Carolina, USA. Mar Ecol Prog Ser 171:109-121

Fonseca MS, Koehl MAR, Kopp BS (2007) Biomechanical factors contributing to self-organisation in seagrass landscapes. J Exp Mar Biol Ecol 340:227-246

Greve TM, Borum J, Pedersen O (2003) Meristematic oxygen variability in eelgrass (Zostera marina). Limnol Oceanogr 48:210-216

Hemminga MA (1998) The root/rhizome system of seagrasses: An asset and a burden. J Sea Res 39:183-196

Hemminga MA, Duarte CM (2000) Seagrass ecology. Cambridge University Press, Cambridge

Kemp WM, Sampou PA, Garber J, Tuttle J, Boynton WR (1992) Seasonal depletion of oxygen from bottom waters of Chesapeake Bay: roles of benthic and planktonic respiration and physical exchange processes. Mar Ecol Prog Ser 85:137-152

Koch EM (1994) Hydrodynamics, diffusion-boundary layers and photosynthesis of the seagrasses Thalassia testudinum and Cymodocea nodosa. Mar Biol 118(4):767-776

Koch EW, Ackerman JD, Verduin JJ, van Keulen M (2006) Fluid dynamics in seagrass ecology-from molecules to ecosystems In: Larkum AWD, Orth RJ, Duarte CM (eds) Seagrasses: biology, ecology and conservation. Springer, Dordrecht, p 193-225

Lee KS, Park SR, Kim YK (2007) Effects of irradiance, temperature, and nutrients on growth dynamics of seagrasses: a review. J Exp Mar Biol Ecol 350:144-175

Mann KH (2000) Ecology of coastal waters with implications for management. Blackwell Science, Boston, MA

> Olivé I, Brun FG, Vergara JJ, Pérez-Lloréns JL (2007) Effects of light and biomass partitioning on growth, photosynthesis and carbohydrate content of the seagrass Zostera noltii Hornem. J Exp Mar Biol Ecol 345:90-100

Pedersen O, Borum J, Duarte CM, Fortes MD (1998) Oxygen dynamics in the rhizosphere of Cymodocea rotundata. Mar Ecol Prog Ser 169:283-288

Peralta G, Pérez-Lloréns JL, Hernández I, Brun FG and others (2000) Morphological and physiological differences between two morphotypes of Zostera noltii Hornem. from the southwestern Iberian Peninsula. Helgol Mar Res 54:80-86

Peralta G, Pérez-Lloréns JL, Hernández I, Vergara JJ (2002) Effects of light availability on growth, architecture and nutrient content of the seagrass Zostera noltii Hornem. J Exp Mar Biol Ecol 269:9-26

Peralta G, Brun FG, Hernández I, Vergara JJ, Pérez-Lloréns JL (2005) Morphometric variations as acclimation mecha-

Editorial responsibility: Hans Heinrich Janssen, Oldendorf/Luhe, Germany nisms in Zostera noltii beds. Estuar Coast Shelf Sci 64: $347-356$

Peralta G, Brun FG, Pérez-Lloréns JL, Bouma TJ (2006) Direct effects of current velocity on the growth, morphometry and architecture of seagrasses: a case study on Zostera noltii. Mar Ecol Prog Ser 327:135-142

Pigliucci M (2001) Characters and environments In: Günter PW (ed) The character concept in evolutionary biology. Academic Press, San Diego, CA, p 363-388

Pregnall AM, Smith RD, Kursar TA, Alberte RS (1984) Metabolic adaptation of Zostera marina (eelgrass) to diurnal periods of root anoxia. Mar Biol 83:141-147

> Puijalon S, Bornette G (2004) Morphological variation of two taxonomically distant plant species along a natural flow velocity gradient. New Phytol 163:651-660

> Schanz A, Asmus H (2003) Impact of hydrodynamics on development and morphology of intertidal seagrasses in the Wadden Sea. Mar Ecol Prog Ser 261:123-134

Smith RD, Dennison WC, Alberte RS (1984) Role of seagrass photosynthesis in root aerobic processes. Plant Physiol 74: 1055-1058

Sokal RR, Rohlf FJ (1995) Biometry: the principles and practice of statistics in biological research. WH Freeman, New York

Sultan SE (1987) Evolutionary implications of phenotypic plasticity in plants. Evol Biol 21:127-178

Sultan SE (2000) Phenotypic plasticity for plant development, function and life history. Trends Plant Sci 5:537-542

Sultan SE, Wilczek AM, Bell DL, Hand G (1998) Physiological response to complex environments in annual Polygonum species of contrasting ecological breadth. Oecologia 115: 564-578

Thomas FIM, Cornelisen CD (2003) Ammonium uptake by seagrass communities: effects of oscillatory versus unidirectional flow. Mar Ecol Prog Ser 247:51-57

Underwood AJ (1997) Experiments in ecology. Cambridge University Press, Cambridge

> van Katwijk MM, Hermus DCR (2000) Effects of water dynamics on Zostera marina: transplantation experiments in the intertidal Dutch Wadden sea. Mar Ecol Prog Ser 208:107-118

Vermaat JE, Verhagen FCA (1996) Seasonal variation in the intertidal seagrass Zostera noltii Hornem.: coupling demographic and physiological patterns. Aquat Bot 52: 259-281

> Wicks EC, Koch EW, O'Neil JM, Elliston K (2009) Effects of sediment organic content and hydrodynamic conditions on the growth and distribution of Zostera marina. Mar Ecol Prog Ser 378:71-80

Zimmerman RC (2003) A biooptical model of irradiance distribution and photosynthesis in seagrass canopies. Limnol Oceanogr 48:568-585

> Zimmerman RC, Kohrs DG, Steller DL, Alberte RS (1995) Carbon partitioning in eelgrass (regulation by photosynthesis and the response to daily light-dark cycles). Plant Physiol 108:1665-1671

Submitted: January 20, 2009; Accepted: September 30, 2009 Proofs received from author(s): December 14, 2009 